Голоюх, Лариса. «Ідіолект Лесі Українки в історії української літературної мови». Лінгвостилістичні студії, вип. 12, 2020, с. 28-36.

Goloyukh, Larysa. "Lesya Ukrainka's Idiolect in the History of the Ukrainian Literary Language". Linguostylistic Studies, iss. 12, 2020, pp. 28-36.

УДК 811.161.2'282.2-112:821.161.2'05-1/9.09Українка

https://doi.org/10.29038/2413-0923-2020-12-28-36

\title{
ІДІОЛЕКТ ЛЕСІ УКРАЇНКИ В ІСТОРІЇ УКРАЇНСЬКОЇ ЛІТЕРАТУРНОЇ МОВИ
}

\author{
Лариса Голоюх \\ Східноєвропейський національний університет імені Лесі Українки, \\ Луцьк, Україна
}

У статті висвітлено роль ідіолекту Лесі Українки в історії української літературної мови. Доведено, що письменниця збагатила художній, науковий, публіцистичний стилі, поповнила епістолярій та перекладну літературу; ідіолект Лесі Українки значно розширив виражальні можливості літературної мови, вивів її за межі українських реалій, наблизив українського читача до класичної і європейської літератури. Мова художніх і наукових текстів Лесі Українки демонструє високий рівень розвитку української літературної мови кінця XIX - початку XX ст.

Ключові слова: ідіолект Лесі Українки, історія української літературної мови, мовна норма, варіанти української літературної мови.

\section{LESYA UKRAINKA'S IDIOLECT IN THE HISTORY OF THE UKRAINIAN LITERARY LANGUAGE Larysa Goloyukh}

Lesya Ukrainka Eastern European National University, Lutsk, Ukraine

The article highlights the role of Lesya Ukrainka's idiolect in the history of the Ukrainian literary language. The writer enriched her artistic, scientific and journalistic styles, supplemented her epistolary and translated literature. Lesia Ukrainka's idiolect significantly expanded the expressive possibilities of literary language, took it beyond Ukrainian realities, and brought the Ukrainian reader closer to classical and European literature: translations of works by Homer, Dante, Byron, Shakespeare, and others. The linguistic aesthetics of Lesya Ukrainka's poetry was formed on the basis of vernacular and folk poetic language in combination with the literary and written traditions of the Ukrainian classics. The vocabulary of Lesya Ukrainka's poems demonstrates a high level of the Ukrainian literary language development. Lesya Ukrainka's poetry conveys complex concepts of art, aesthetics, science, including philosophy, psychology, history, art, and aesthetics. We can find verbal incarnations of the image of the Word in the idiolect of the writer. Most of the events in Lesya Ukrainka's plays take place in Ancient Greece, Ancient Rome, Spain, Egypt, Germany, North America and other countries. Lesya Ukrainka's dramas are rich in aphorisms - individual-author maxims. Most of the aphorisms concern the artistic theme of slavery, slavery - freedom, liberty. Various socio-political topics are among the civic interests of the writer, which are reflected in her journalistic works. Lesya Ukrainka is the author of literary-critical and scientific works. The idiolect of the writer significantly complements her epistolary legacy. She adhered to Eastern

(C) Голоюх Л., Східноєвропейський національний університет імені Лесі Українки, 2020.

Це стаття відкритого доступу на умовах CC BY-NC 4.0 
Ukrainian language traditions and consistently used lexical and grammatical language forms of Western Ukraine.

Key words: Lesia Ukrainka's idiolect, the history of the Ukrainian literary language, language norm, variants of the Ukrainian literary language.

Вступ. Ідіолект Лесі Українки - феноменальне явище в історії української літературної мови. Письменниця збагатила художній, науковий, публіцистичний стилі, поповнила епістолярій та перекладну літературу. Її перу належить лірика, епос, драма, проза, публіцистика, літературно-критичні праці, переклади світової літератури і листи. Л. І. Мацько слушно зазначає: «Досі не вичерпано мовну стилістику жанрів Лесі Українки. Це поезії - гімни, пісні, заспіви, сонети, елегії, мелодії, мотиви, спогади, веснянки, колискові, казки, феєрії, відгуки, імпровізації, легенди, монологи, фантазї, гуморески, нотатки. Мозаїка малої прози: оповідання й нариси, образки й образочки, спогади, легенди й силуети, поетична й прозова, часто поетична в прозі епістолярія Лесі Українки, літературно-публіцистичні статті, огляди, рецензії. Такого букету жанрів не тільки до Лесі, а й після неї важко знайти» (142). Ідіолект Лесі Українки був об'єктом дослідження С. Я. Єрмоленко, Л. О. Мацько, В. М. Русанівського, Л. О. Ставицької, О. Б. Ткаченка, Я. В. Януш та інших учених.

Мета дослідження - акцентувати увагу на домінантних аспектах ідіолекту Лесі Українки та його актуалізації в історії української літературної мови.

Матеріал і методи дослідження. Матеріал статті - зібрання творів Лесі Українки у дванадцяти томах.

У дослідженні використано метод комплексного аналізу, що поєднує різні види дослідження ідіолекту: лінгвістичний, літературознавчий, культурологічний тощо; метод компонентного та контекстуального аналізу для виявлення семантики і лінгвостилістичних функцій ключових одиниць текстів різних жанрів.

Результати дослідження та дискусія. Якщо говорити про мовну особистість Лесі Українки, реалізовану в її художніх, наукових, публіцистичних та епістолярних текстах варто згадати слова авторитетних учених. В. М. Русанівський так висловлюється про мовний світ письменниці: «Це високоінтелігентна мова, абсолютно позбавлена навіть натяку на «котляревщину». Мова Лесі Українки - це на початок XX ст. зразок інтелігентної літературної мови Східної України» (268). Л. О.Ставицька називає лірику Лесі Українки поезією духовного аристократизму (14). С.Я. Єрмоленко наголошує на тому, що «iї мовотворчість піднесла інтелектуальний рівень української літературної мови» (Єрмоленко, «Нариси» 162). Видатний мовознавець сучасності Ю. Шевельов визначив Лесю Українку як людину високої загальної і мовної культури (92).

Закономірно виникає питання про те, чим можна виміряти внесок письменника в українську літературну мову. С. Я. Єрмоленко вважає, що однією з ознак значного внеску письменника в літературну мову $\epsilon$ 
впізнаваність створених ним образів (Єрмоленко, «Мовно-естетичні» 299). Так, за образами Дніпр широкий, садок вишневий коло хати, думи мої, думи мої ми безпомилково впізнаємо Т. Шевченка; слова Чому являєшся мені у сні, зів'яле листя, вічна гра світла й тіней - мовні знаки ідіолекту I. Франка; рядки Той цвіт від папороті чарівніший, він скарби творить, а не відкриває, Хай же та мрія із думкою вкупі лине в незнані світи, $\mathrm{Hi}$, я жива, я буду вічно жити..., Гетьте, думи, ви хмари осінні; Прощай, Волинь, прощай, рідний куточок - одиниці мовомислення Лесі Українки.

У «Словнику української мови» на мову кожного письменника припадає приблизно по пів відсотка ілюстрацій уживання слів. Цитати 3 творів Лесі Українки становлять 4,5\% всіх ілюстрацій, тобто вони трапляються на сторінках словника в 9 разів частіше, ніж цитати інших авторів. С.Я. Єрмоленко зазначає: «Показовим $\epsilon$ те, що поряд 3 ілюстраціями до реєстрових слів, взятими з творів Лесі Українки, бачимо цитати $з$ творів не лише іï попередників і сучасників, а й письменників наступних літературних поколінь» (Єрмоленко, і Ставицька 8). «Словник української мови» фіксує номінації з різних сфер людського життя, проте найчастотніші 3 них - книжні слова абстрактної семантики: ідеалізм, ідеальність, ідея, ілюзія, ілюструвати, імітація, імпровізувати, імпровізаторський та ін. Приклади книжного слововжитку (камінь спотикання) і розмовних формул (каменем сидіти) демонструють синтез писемно-книжної і народно розмовної стихій в ідіолекті Лесі Українки доводить, що письменниця збагатила лексичний склад української мови.

Ідіолект Лесі Українки значно розширив виражальні можливості літературної мови, вивівши i за межі українських реалій. В. М. Русанівський зазначає: «За 50 років до Хвильового Леся Українка прагнула розбити мури української літературно-культурної замкнутості. Скільки вона сама зробила особисто, щоб прилучити українського читача до класичної і європейської літератури: це переклади творів Гомера, Данте, Байрона, Шекспіра, Дж. Свіфта, Гейне, Тургенєва, Надсона, Гюго та ін. Взагалі ж їі мрією було видання українською мовою бібліотеки іноземної літератури, зокрема творів Байрона, Бальзака, Бомарше, Поля Бурже, Вольтера, Гаршина, Короленка, Конопніцької, Леопарді, Леконта де Лілля, Мольєра, Петрарки, Руссо, Сервантеса, Вальтера Скотта, Сирокомлі, Сталь, Шеньє...» (269). Ідіолект Лесі Українки ввібрав традиції високорозвинених мов світу і кращих творів класичної літератури, синтезував їхні компоненти в індивідуальному художньому світосприйманні.

Народнорозмовна і народнопоетична мова в поєднанні 3 літературно-писемними традиціями українських класиків, насамперед Шевченка, світової літератури, зокрема західноєвропейських письменників, сформували ідіолект Лесі Українки. Високий рівень розвитку української літературної мови кінця XIX - початку XX ст. демонструє поезія Лесі Українки, в якій зафіксовано складні поняття мистецтва, естетики, науки, зокрема філософії, психології, історії, 
мистецтва, естетики: 1) міжгалузеві, або загальнонаукові, терміни: паралель, тенденція, аналіз; 2) філософська термінологія: вічне, часове, матерія, буття, ідея, самопізнання; стійкі сполуки: вічність матерії, аристократ вічної ідеї; 3) літературні терміни: вірш, казка, байка, епіграма, ода, балада, поема, монолог, імпровізація, елегія; 4) музична термінологія: сонет, рондо, ноктюрн, романс, мелодії, мотив, пісня, фортеп'яно, орган, кобза, скрипка, флейта, арфа, акорд, гама, увертюра; 5) терміни скульптури і малярства: фігура, портрет, ескіз, статуя, скульптура, n'єдестал, митець, мистець; 6) архітектурні терміни: палаци білі, мармурове місто, мавзолей, арка, аркада, колона, колонада, галерея, мозаїка.

Слово - ключовий концепт поетичних творів Лесі Українки. В ідіолекті письменниці зафіксовані такі вербальні втілення цього образу: словозброя, слово-птиця, слово-вогонь, слово-меч; слово - живеє, прудке, щире, тихе, таємне, громовеє, вільне, добре, вогнисте, веселе, плідне; слова благословенні, багряні, вразливі, гарячі, голосні, журливі, необачні, непокірні, невтримні, палкі, пророчі. Слово має не лише позитивне художнє навантаження, а й об'єднує широкий спектр епітетів із різними семами негативу, драматизму, трагізму: слова - безжалісні, безладні, безумні, бридкі, ворожі, бридкі, даремні, жалісні, зловісні, згірдні, марні, недобрі, німі, погані тощо.

Автори підручників 3 української літератури традиційно наголошують на художній паралелі слово - зброя, слово - криця, тобто образові слова як засобу боротьби. Такий підхід звужує мовну картину світу й естетичну систему Лесі Українки. Л. О. Ставицька і С. Я. Єрмоленко звернули увагу на мотив невимовленого слова: Якби мої думи німії та піснею стали без слова, тоді б вони більше сказали, ніж вся оця довга розмова; Ті скарби, що лежать в душі на дні, ті скарби, що для мене таємні, та мріється, що так вони коштовні, як ті слова, що вголос невимовні (Єрмоленко, і Ставицька 11).

Один із ключових образів поетичних текстів Лесі українки - думи $i$ мрії, наприклад: Хай же та мрія із думкою вкупці лине в незнані світа (Українка 1: 113). Художня парадигма мрія, думка, сон формує образний ряд внутрішнього простору поетеси. Л. О. Ставицька зауважує: «це все-таки дві субстанції. Мрії - думки співвідносяться як душа - розум. Думка - це раціональне осмислення реального буття: Гетьте, думи, ви хмари осінні; Думки-гадки, мов птахи нічнії, налетіли, тяжкі та суворі. Номінація мрії мовний знак радості, щастя, наприклад: Знов мене колишуть мрії, сни про щастя навівають; Коли я смуток свій на струни клала, з'являлась ціла зграя красних мрій (Єрмоленко, і Ставицька 11).

В ідіолекті Лесі Українки, крім літературно-книжних, функціонують фольклорно-пісенні образи: квіти, рута зелененька, дівчина молоденька, синє море, сира земля, ясна нічка, зоря ясні, біленькі хати, садочок, соловейко. Фольклорно-пісенний лад поезій виявляється і завдяки 
вживанню традиційних для усно-народного словотвору парних слів. Наприклад: плакати-ридати, плаче-тужить, туга-журба, туга-жаль, думки-гадки, срібло-злото, огонь-блискавиця, буря-хуртовина, час-пора, отець-мати, дівчина-рожа, пісні-слова, дзвенять-бринять та ін. За зразком народнопоетичних парних слів письменниця створила оказіоналізми: думи-хвилі, думи-вампіри, думи-чарівниці, пісня-отрута, сльози-співи, римисоколята, лицарство-козацтво. Складні слова - оказіоналізми: срібнострунні арфи, квітка ломикамінь, громовладиі, землерушителі.

Драматичні твори Лесі Українки демонструють і високий рівень української літературної мови того часу, і потенційну спроможність української мови бути засобом вербалізації «високих» тем: релігійних, історичних, культурних, гуманістичних, патріотичних тощо. Дія більшості драматичних творів Лесі Українки відбувається у країнах, далеких від України. Це Стародавня Греція («Оргія»), Троя («Кассандра»), стародавня Іудея («На руїнах»), Італія («Забута тінь»), Іспанія («Камінний господар»), Німеччина, Північна Америка, Франція, стара Шотландія, Єгипет та інші країни.

На думку О.Б. Ткаченка, кілька обставин склалося так, щоб письменниця на ймення Українка мала звернутися до неукраїнських сюжетів. Це було спричинено такими обставинами. По-перше, знання іноземних мов: класичних латинської і грецької, західноєвропейських мов і слов'янських мов: російської, польської, болгарської. По-друге, глибока ерудиція, здобута ще в молодості. А. Кримський згадує, що письменниця нерідко радилася з приводу літератури, щоб правдиво відтворити добу раннього християнства в Римі. По-третє, необхідність вдаватися в той час до «езопівської мови». Часто для того, щоб передати вільну думку, письменниця застосовувала іносказання. О.Б. Ткаченко вважає, що українська тематика надала б їі творам побутового звучання. Учений зазначає і таке: «У їі драмах українська мова лунає з уст грецьких царів, римських патриціїв, біблійних i євангельських пророків, іспанських грандів і грандес, французьких революціонерів, i ми ні на мить не відчуваємо в цьому ніякої неприродності. Усією логікою своєї творчості і по-мистецьки відшліфованого слова Леся Українка неспростовно доводить, що українська мова цілком природна в устах найрафінованішої інтелігенції, найвищого і найвишуканішого товариства... Майбутньому українському суспільству, яке щойно народжувалося, поетеса дала блискучі зразки того, як можна і треба говорити українською мовою на найскладніші теми» (12).

Я. В.Януш звертає увагу на незаперечну роль Лесі Українки в піднесенні інтелектуального рівня української літературної мови завдяки драматичним творам: «У драматичних творах письменниці знайшов відображення такий спосіб поповнення абстрактного лексикону української літературної мови, як розвиток конкретними загальновживаними 
словами абстрактних значень, що теж сприяло інтелектуалізації й посиленню її виражальних можливостей» (210).

Драми Лесі Українки багаті на афоризми - індивідуально-авторські сентенції, влучні вислови, які мають мовну природу і позамовний зміст. Леся Українка не створювала спеціально афоризми. Проте, на думку С. Єрмоленко, ïi ліро-епічні твори і драми мають класичні ознаками «крилатості» (Єрмоленко, «Мовно-естетичні» 154). Велика частина афоризмів розгортає художню тему неволя, рабство - воля, свобода, життя - смерть, наприклад: Хто визволиться сам, той буде вільний, Хто раб? Хто подоланий? Тільки той, хто самохіть несе ярмо в неволі; Ні! Я жива! Я буду вічно жити.

У колі громадянських інтересів письменниці були різні суспільнополітичні теми, які відбилися в ї̈ публіцистиці. Це статті «Лист до товаришів», «Безпардонний патріотизм», «Не так тії вороги, як добрії люди». На жаль, не всі публіцистичні праці письменниці збереглися. Відомо, що її стаття про автономію України була надіслана до газети Русь, але не була надрукована, і доля її невідома. Втрачені і деякі інші праці.

Публіцистика Лесі Українки часто має наукове спрямування. Деякі їі дослідження торкаються мовних проблем. У статті «Спогади про Миколу Ковалевського» Леся Українка розкриває проблеми формування наукового стилю на початку XX століття, відзначаючи його слабкий розвиток в умовах заборон українського слова і функціонування в неофіційному вжитку. На її думку, в умовах розпорошеності українських земель по двох імперіях ділового стилю майже не існувало, бо українською мовою не здійснювалося ні діловодство, ні законотворчість. У статті «Державний лад» вона пише: «Люди, що говорять нашою мовою, живуть у Росії, менша частина в Австрії, в Галичині, а звідки ж його знати простому чоловікові, що по вищих школах не бував і навіть прочитати тих законів не вміє, а хоч і прочитає, то навряд чи розбере, бо в Австрії вони написані по-німецьки, а в Росії по-російськи, та часом так круто, що не кожний і вчений одразу второпає».

У часи бездержавності, заборон українського слова Леся Українка виразно усвідомлювала важливість літературної мови як ознаки

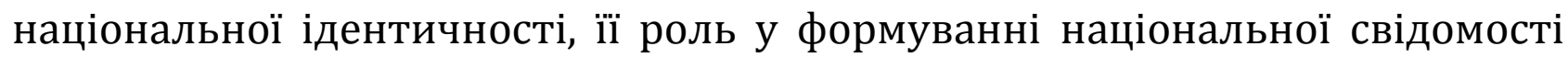
українців. «У мовних дискусіях кінця XIX - початку XX ст. вона як духовна вихованка Михайла Драгоманова, сучасниця Івана Франка i Михайла Грушевського, підтримувала і продовжувала нову філософію літературної української мови, що виявлялася у вимогах і потребах зняти заборони i обмеження 3 української мови, розширити функціональне поле української мови» (Мацько, і Сидоренко 140).

Леся Українка - авторка літературно-критичних праць «Два напрями в новітній італійській літературі», «Українські письменники на Буковині», «Замітки про новітню польську літературу», незакінчена стаття про 
В. Винниченка. У праці «Утопія в белетристиці» письменниця досліджує стилістичні відмінностями між жанрами біблійних творів.

Ідіолект письменниці суттєво доповнює ії епістолярна спадщина, адже листи - це природній вияв внутрішнього світу людини, стану її душі, часто прихований від масового читача. С. К. Богдан зазначає: «Головне - що Лесина епістолярія дає можливість реконструювати (бодай схематично) справді неповторну індивідуальну мовноповедінкову систему, відтворити продуктивні моделі мовноетикетних стереотипів» (291). Зосереджуючи увагу на стилі епістолярію Лесі Українки, С. Я. Єрмоленко називає його світом іншомовних літератур, трансформованих в український інтелектуальний контекст, мовним європеїзмом в українському контексті. «Поряд співіснують українська приказка, народний дотеп і французький усталений вислів, польський фразеологізм і латинський афоризм, російський літературний зворот і поетичний рядок із відомого твору українського письменника» (Єрмоленко, «Нариси» 155). В одному з листів до М. Драгоманова Леся Українка пише: «Хочу в кінці мая рушити з тіткою до Полонного, звідти одбігти до Звягля» - «Schöne Wiege meiner Leiden»[Прекрасна колиска моїх страждань - нім. ред.], - а потім вже податись до Гадяча» (Українка 10: 152).

Листування Лесі Українки відкриває дослідникам не лише фрагменти особистого життя письменниці, а й доповнює їі лінгвокультурний i громадянський портрет. Леся Українка в листах пише про різні теми: писемні стилі тогочасної української літературної мови, необхідність національно-мовної політики в Галичині на користь українців, галицьку писемну практику, зросійщення української інтелігенції, оцінку суспільнополітичних і культурних реалій кінця XIX - початку XX ст. та ін.

Леся Українка висловлювала думки з приводу роз'єднаності України і двох варіантів мови - східного і західного. Письменниця ставилася негативно до галицької наукової мови за її бідність, а також засмічення неологізмами й іншомовними словами, про що писала в листі до М. Драгоманова. У листі до 0. Маковея вона зазначала: «Я не знаю, чим це об'яснити, тільки галичани краще говорять, ніж пишуть, а українці краще пишуть, ніж говорять. Я мушу сказати, що вихована я в українській мові» (Українка 10: 180). У листуванні $з$ галицькими і буковинськими письменниками i громадськими діячами Лесі українка порушувала питання про вироблення загальноукраїнських мовних норм, сприяла поширенню правил фонетичного правопису. Письменниця у своїх листах часто торкалася теми вивчення іноземних мов, що для самої поетеси було дуже важливим $\mathrm{i}$ в плані самоосвіти, і в аспекті наближення України до європейської культури. Отже, листи - це тексти, які суттєво доповнюють мовний портрет письменниці.

Л. І. Мацько зазначає: «На всьому спектрі літературних і зокрема поетичних жанрів - від колискової «Місяць яснесенький...», дитячих вишеньок-черешеньок, казочки «Біда навчить» до найскладнішого епіко- 
ліричного жанру драматичних поем - Леся Українка створила такі естетичні вартості української мови, які й досі гідно репрезентують у європейській культурі і національний дух, і загальнолюдський сенс українського буття» (Мацько, і Сидоренко 141).

Лінгвісти називають Лесю Українку представницею східного варіанта української літературної мови. Письменниця не брала участі в мовних дискусіях, але її художні, наукові та епістолярні твори свідчать, що вона дотримувалася східноукраїнських мовних традицій і послідовно застосовувала лексичні і граматичні мовні форми Західної України.

Висновки і перспективи дослідження. Отже, ідіолект Лесі Українки позначився на формуванні художнього та епістолярного стилів української літературної мови, збагатив мовно-виражальні засоби художнього стилю, вплинув на вироблення наукового і публіцистичного стилів літературної мови ï доби. Зважаючи на невеликий обсяг статті, перспективою дослідження має бути глибокий аналіз художніх, епістолярних, наукових і публіцистичних текстів Лесі Українки з проєкцією на мовну практику кінця XIX - початку XX століття, а також норми сучасної української літературної мови.

\section{Список використаної літератури}

Українка, Леся. Зібрання творів. В 12 т. Київ: Наукова думка, 1975-1979.

Богдан, Світлана. «Листування як визначальний елемент мовленнєвої діяльності Лесі Українки». Леся Українка і сучасність, т. 2. Луцьк: Волинська обласна друкарня, 2005, с. 291-315.

Єрмоленко, Світлана. Нариси з украӥнської словесності: (стилістика та культура мови). Київ: Довіра, 1999.

Єрмоленко, Світлана. Мовно-естетичні знаки української культури. Київ: Інститут української мови НАН України. 2009.

Єрмоленко, Світлана, і Ставицька, Леся. «"Не міряй ти безмірного безкраїм” (До 120річчя Лесі Українки)». Мовознавство, № 2, 1991, с. 7-14.

Мацько, Любов, і Сидоренко, Олеся. «Лінгвостилістичний погляд на мовний світ Лесі Українки». Лінгвостилістичні студії, вип. 1, 2014, с. 135-45.

Русанівський, Віталій. Історія украӥнської літературної мови. Київ: АртЕк, 2001.

Ставицька, Леся. «Лексична структура поетичної реальності у ліриці Лесі Українки». Культура слова, вип. 59, 2001, с. 14-9.

Ткаченко, Орест. «Іноземний світ Лесі Українки». Культура слова, вип. 39, 1990, с. 10-20.

Шевельов, Юрій. Внесок Галичини у формування української мови. Київ: Видавничий дім «КМ Академія», 2003.

Януш, Ядвіга. Роль Лесі Українки в інтелектуалізації української літературної мови. Леся Українка і сучасність, т. 4, кн. 2, Луцьк: Вежа, 2008, с. 210-20.

\section{References}

Ukrainka, Lesia. Zibrannia tvoriv. 12 vols. Kyiv: Naukova dumka, 1975-1979.

Bohdan, Svitlana. "Lystuvannia yak vyznachalnyi element movlennievoi diialnosti Lesi Ukrainky”. Lesia Ukrainka i suchasnist, vol. 2. Lutsk: Volynska oblasna drukarnia, 2005, pp. 291-315.

Yermolenko, Svitlana. Narysy z ukrainskoi slovesnosti: (stylistyka ta kultura movy). Kyiv: Dovira, 1999. 
Yermolenko, Svitlana. Movno-estetychni znaky ukrainskoi kultury. Kyiv: Instytut ukrainskoi movy NAN Ukrainy. 2009.

Yermolenko, Svitlana, and Stavytska, Lesia. “"Ne miriai ty bezmirnoho bezkraim” (Do 120richchia Lesi Ukrainky)”. Movoznavstvo, № 2, 1991, pp. 7-14.

Matsko Lyubov, and Sydorenko, Olesya. "The Linguistic view on World Language Lesya Ukrainka's". Linguostylistic Studies, iss. 1, 2014, pp. 135-45.

Rusanivskyi, Vitalii. Istoriia ukrainskoi literaturnoi movy. Kyiv: ArtEk, 2001.

Stavytska, Lesia. «Leksychna struktura poetychnoi realnosti u lirytsi Lesi Ukrainky». Kultura slova, iss. 59, 2001, pp. 14-9.

Tkachenko, Orest. «Inozemnyi svit Lesi Ukrainky». Kultura slova, iss. 39, 1990, pp. 10-20.

Shevelov, Yurii. Vnesok Halychyny u formuvannia ukrainskoi movy. Kyiv: Vydavnychyi dim "KM Akademiia", 2003.

Yanush, Yadviha. "Lesya Ukrainka's Role in the Ukrainian Standard Language Intellectualization Process", Lesia Ukrainka i suchasnist, vol. 4, part 2, Lutsk: Vezha, 2008, pp. 210-20.

Стаття надійшла до редколегії 17.11.2019 